\title{
Analisis Sentimen Masyarakat Jakarta Terhadap Kebijakan Perluasan Dan Perpanjangan Ganjil Genap di Media Sosial Twitter
}

\author{
Nur Sucahyo $^{1{ }^{* *}}$, Lela Nurlaela ${ }^{2)}$, Robbi Rekto Waryono ${ }^{3)}$ \\ ${ }^{13)}$ Prodi Sistem Informasi, Fakultas Teknologi, ITB Swadharma \\ ${ }^{2}$ Prodi Teknik Informatika, Fakultas Teknologi, ITB Swadharma \\ ${ }^{*}$ Correspondence Author: nursucahyo@ @wadharma.ac.id, Jakarta, Indonesia \\ DOI: https://doi.org/10.37012/jtik.v7i1.506
}

\begin{abstract}
Abstrak
Sosial media kini telah menjadi budaya baru dalam rutinitas sehari-hari. Sosial media hadir sebagai wadah untuk berbagi informasi. Namun dalam perkembangannya, sosial media bukan lagi sekedar berbagi informasi tapi sebagai wadah menyampaikan pendapat, kritik, saran dan komplain kepada instansi tertentu. Data Badan Pusat Statistik DKI Jakarta tahun 2016, jumlah kendaraan bermotor yang terdaftar sebanyak 11.839.921 unit dengan jumlah sebanyak itu jika tidak diimbangi dengan pertumbuhan pembangunan jalan yang signifikan maka kemacetan akan bertambah parah setiap tahunnya di DKI Jakarta. Dengan penerapan kebijakan ganjil genap diharapkan kemacetan dapat berkurang dan masyarakat berlaih menggunakan transportasi umum yang telah tersedia. Penelitian dilakukan dengan cara menganalisa sentimen masyarakat berupa respon postif, netral atau negatif pada media sosial twitter. Algoritma Nä̈ve Bayes Classifier digunakan untuk mengklasifikasikan ke dalam sentimen positif, netral dan negative. Data diperoleh dengan cara crawling pada media sosial twitter pada bulan maret sampai mei 2019. Hasil penelitian memperoleh data sebanyak 3117 baris kemudian diprosentasekan menjadi 5.38\% sentiment positif $14.54 \%$ sentimen negatif dan $80.08 \%$ sentimen netral. Dengan hasil tersebut, sentimen netral mendominasi. Hal ini disebabkan oleh beberapa hal diantaranya yaitu respon masyarakat yang cenderung tidak peduli terhadap kebijakan ganjil genap dan proses pengambilan data dilakukan pada saat ganjil genap tidak menjadi trending.
\end{abstract}

Kata kunci: Analisis sentimen, naïve bayes, twitter

\begin{abstract}
Social media has now become a new culture in our daily routine. Social media exists as a place to share information. However, in its development, social media is no longer just sharing information but as a forum for conveying opinions, criticisms, suggestions and complaints to certain agencies. Data from the DKI Jakarta Central Statistics Agency in 2016, the number of registered motor vehicles was 11,839,921 units, with that number if not balanced with significant road development growth, congestion will get worse every year in DKI Jakarta. By implementing the odd-even policy, it is hoped that congestion can be reduced and people can reach to use the available public transportation. The research was conducted by analyzing public sentiment in the form of positive, neutral or negative responses on social media twitter. The Naïve Bayes Classifier algorithm is used to classify positive, neutral and negative sentiments. The data was obtained by crawling on social media twitter from March to May 2019. The results of the study obtained 3117 lines of data which were then proxied to be $5.38 \%$ positive sentiment, $14.54 \%$ negative sentiment and $80.08 \%$ neutral sentiment. With this result, neutral sentiment dominates. This is due to several things, including the response of the community that tends not to care about odd-even policies and the data collection process is carried out when the odd-even is not trending.
\end{abstract}

Keywords: Sentiment analysis, Nä̈ve Bayes, Twitter 


\section{PENDAHULUAN}

Kehadiran sosial media di tengah masyarakat telah merubah kebiasaan cara berkomunikasi. Dahulu orang berkomunikasi secara langsung untuk bertukar informasi, pengalaman dan berita. Koran, radio dan televisi merupakan media yang digunakan oleh orang-orang untuk mencari berita dan informasi. Namun dengan adanya sosial media saat ini orang lebih memilih berbagi informasi, pengalaman, foto dan video yang dimiliki melalui media sosial. Kebiasaan tersebut dapat dimanfaatkan oleh pemerintah untuk sosialisasi peraturan/kebijakan yang akan diberlakukan. Saat pemerintah akan menerapkan peraturan/kebijakan, harus dilakukan uji coba untuk mengetahui tanggapan dari masyarakat. Untuk itu media sosial dipilih sebagai sarana untuk sosialisasi peraturan tersebut dan untuk mengetahui respon masyarakat terhadap peraturan/kebijakan yang akan diterapkan. Kebijakan yang akan diterapkan dalam waktu dekat ini di wilayah DKI Jakarta adalah sistem ganjil/genap untuk kendaraan bermotor. Mekanisme peraturan ini adalah kendaraan bernomor polisi ganjil hanya diperbolehkan melintas di tanggal ganjil dan kendaraan bernomor polisi genap hanya diperbolehkan melintas di tanggal genap. Langkah ini dilakukan untuk mengurangi kemacetan dan membatasi jumlah kendaraan yang melintas di Jakarta.

Berdasarkan data dari Badan Pusat Statistik DKI Jakarta tahun 2016, jumlah kendaraan bermotor yang terdaftar sebanyak 11.839.921 unit (BPS DKI Jakarta, 2019), jumlah tersebut tidak termasuk kendaraan TNI, Polri dan kendaraan dinas lainnya. Dengan jumlah sebanyak itu, jika tidak diimbangi dengan pertumbuhan pembangunan jalan yang signifikan di DKI Jakarta maka kemacetan akan bertambah parah setiap tahunnya. Dengan penerapan kebijakan ganjil/genap diharapkan kemacetan dapat berkurang dan masyarakat beralih menggunakan alat transportasi umum yang telah tersedia.

Penerapan uji coba ganjil/genap di DKI Jakarta yang telah dilakukan memunculkan berbagai respon dari masyarakat. Ada yang mendukung kebijakan tersebut, ada yang bersikap netral dan tidak sedikit yang menolak kebijakan terserbut. Sebagian besar masyarakat menyampaikan respon melalui media sosial salah satunya twitter. Media twitter dipilih karena jumlah pengguna yang banyak dan kemudahan akses. Sebelumnya pernah dilakukan penelitian mengenai sentimen analis penerapan ganjil genap pada twitter (Ruhyana, 2019; Yanti, Indriati, \& Adikara, 2019) namun data dari hasil peneltian belum divisualisasikan dengan baik, informasi yang ditampilkan masih minim untuk diberikan kepada publik. Untuk itu penelitian ini akan menghasilan informasi yang dapat diakses 
publik dengan hasil pengolahan data ditampilkan secara visual menggunakan grafis agar dapat lebih mudah dipahami oleh publik.

Twitter merupakan media jejaring sosial besar yang berfokus komunikasi cepat. Lebih dari 140 juta pengguna aktif mempublikasikan lebih dari 400 juta karakter "tweets" setiap hari. Twitter telah menjadi media komunikasi yang penting bagi semua lapisan masyarakat. Twitter telah berperan penting dalam berbagai peristiwa sosial dan politik (Kumar, Morstatter, \& Liu, 2014). Dalam pengambilan data untuk analisis sentimen, Twitter menyediakan Aplication Programming Interface (API). Ada dua jenis API yang dapat digunakan RESTAPI dan StreamingAPI. RESTAPI digunakan untuk mengakses status dan user timeline. Streaming API digunakan untuk mengakses kata kunci, hashtags, ID pengguna, dan lokasi.

Klasifikasi adalah proses menentukan suatu objek ke dalam suatu kelas atau kategori yang telah ditentukan. Penentuan objek dapat menggunakan suatu model tertentu. Beberapa model yang bisa digunakan antara lain : classification (IF-THEN) rules, decision trees, formula matematika atau neural networks (Han, Kamber, \& Pei, 2012). Naïve Bayes Classifier (NBC) merupakan metode yang berdasarkan atas probabilitas bayes untuk melakukan pengelompokan data (Ruhyana, 2019).

Berdasarkan permasalahan tersebut maka dilakukan penelitian mengenai sentimen analisis. Sentimen analisis digunakan untuk merancang strategic information system terhadap penentuan perpanjangan dan perluasan ganjil genap di wilayah DKI Jakarta. Analisis dilakukan pada media sosial twitter agar diperoleh hasil penelitian yang digunakan sebagai bahan pertimbangan dalam penentuan kebijakan tersebut.

\section{METODE}

Pelaksanaan penelitian dilakukan dengan menggunakan metode Cross Industry Standard Process Model for Data Mining (CRISP-DM). Gambar 1 menunjukan alur proses yang terjadi pada CRISP-DM. (, Suhanda Kurniati, \& Norma, 2020). Salah satu keuntungan dari menggunakan metode ini adalah menjelaskan langkah paling umum dalam proses melakukan data mining. 


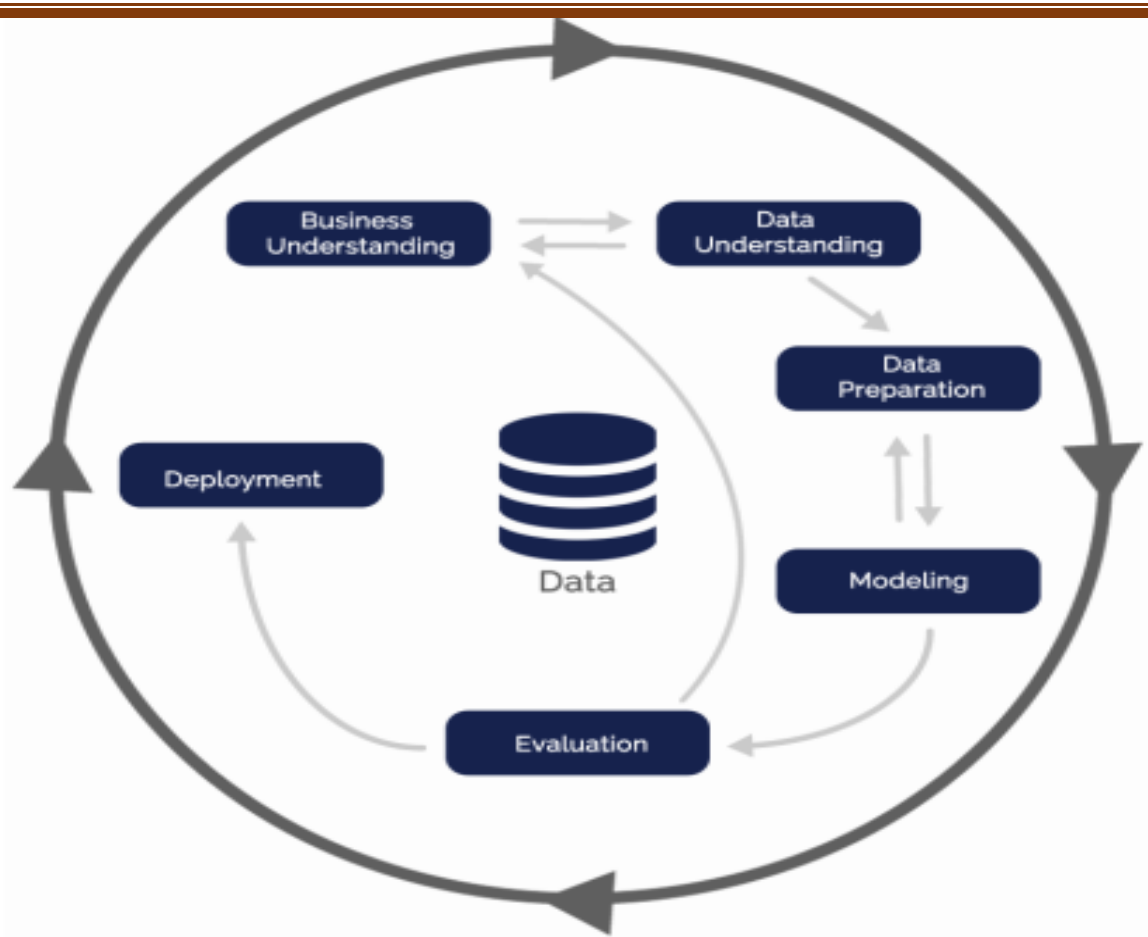

Gambar 1. Alur CRISP DM

CRIPS-DM merupakan standar yang digunakan pada bidang data mining, terbagi atas 6 bagian antara lain sebagai berikut :

1. Business Understanding

Dari permasalahan yang terjadi pada penentuan perpanjangan dan perluasan ganjil genap di wilayah DKI Jakarta, pemerintah daerah tidak mengetahui respon masyarakat terhadap kebjikan tersebut sehingga perlu adanya referensi dalam menentukan perpanjangan dan perluasan ganjil genap tersebut, maka dilakukan analisis sentimen untuk menentukan kebijakan perpanjangan dan perluasan ganjil genap di wilayah DKI Jakarta.

2. Data Understanding

Untuk dapat merancang kebijakan perpanjangan dan perluasan ganjil genap di wilayah DKI Jakarta dengan pendekatan analisis sentimen diperlukan data respon masyarakat dari media sosial twitter melalui proses crwaling dengan periode pengambilan data dari bulan Maret sampai Mei 2019, kendala yang tedapat pada data twitter adalah:

a. Ketersediaan data, twitter hanya membatasi jumlah data yang dapat diambil untuk satu kali proses crawling berdasarkan keyword sebanyak 10.000 data,

b. Data semakin berkurang jika tema sudah jarang dibahas, karena twitter hanya dapat menyimpan data tweet selama 7 hari.

c. Data tweet masih tercampur dengan karakter, tanda baca atau link website sehingga perlu dilakukan pembersihan untuk dapat dimodelkan. 
3. Data Preparation

Data preparation merupakan tahapan untuk memperbaiki masalah yang terdapat pada data sebelum data masuk ke tahap modeling sehingga menghasilkan model yang baik, data preparation terdiri dari beberapa proses antara lain sebagai berikut :

a. Install Library

Untuk menjalankan program $\mathrm{R}$ tertentu diperlukan library yang sesuai agar instruksi/perintah yang diketik dikenali oleh $\mathrm{R}$, Sehingga memerlukan library yang dapat didownload dan diinstal.

b. Autentifikasi Twitter API.

Twitter telah memberikan izin dengan menggunakan API sebagai penghubung antara aplikasi yang digunakan oleh para pengembang untuk melakukan pengambilan data twitter yang berbentuk status timeline, retweet, favourite dan direct message. Jumlah data yang diijinkan oleh twitter untuk di akusisi melalui API sebanyak 10.000 baris dalam setiap kali proses. Dalam hal ini fungsi "search twitter" melakukan pencarian sebanyak $\mathrm{n}=10.000$ baris dengan batasan last period (sepanjang tujuh hari). Dengan demikian jika pencarian dilakukan terhadap $\mathrm{n}$ kategori maka pencarian akan dilakukan pada status tweet recent kemudian mundur kebelakang hingga jumlah $\mathrm{n}$ terpenuhi. Namun jika jumlah pencarian tidak terpenuhi maka jumlah baris akan tampil sebanyak $n$ jumlah baris yang tentunya hasil pencarian lebih kecil dengan $\mathrm{n}$ jumlah.

Untuk mendapatkan autentifikasi dari twitter harus membuat akun twitter terlebih dahulu, setelah akun twitter aktif kemudian gunakan konsumen API keys, Access token dan access token secret untuk melakukan autentifikasi dengan API twitter dengan cara memasukan nomor tersebut kedalam source code

c. Crawling data tweet berdasarkan keyword

Proses pengumpulan pada twitter dengan cara menggunakan kata kunci yang berkaitan dengan penerapan ganjil genap misalkan "penerapan ganjil genap" pada fungsi SearhTwitter, dengan fungsi tersebut semua tweet yang terdapat kata penerapan ganjil genap akan ditarik dari twitter. Proses pengumpulan data akan berlaku untuk semua kata kunci yang telah disiapkan untuk pengumpulan data. Untuk data sampel pengumpulan data dilakukan dengan memberikan batasan jumlah data yang akan diambil, twitter membatasi jumlah data yang akan diambil yaitu sebanyak 10.000 baris untuk satu kata kunci, maka untuk memaksimalkan pengumpulan data akan digunakan batasan yaitu $n=10000$, untuk mendapatkan data 
dengan kategori dalam negeri maka dibatasi hanya pada tweets berbahasa indonesia dengan memasukan kode bahasa lang="in".

d. Data Frame

Data frame merupakan sebuah class, dalam bahasa R. Class harus didefinisikan terlebih dahulu. Data frame berfungsi menyimpan data yang diperoleh dari proses crawling data.

e. Tokenize

Proses tokenize ini ditangani oleh fungsi tokenizer yang berguna untuk merubah kalimat pada data tweet menjadi pecahan kata berdasarkan delimiter yaitu berupa spasi, tanda baca koma (,) titik koma (;) dan titik dua (:), kemudian setiap kata yang telah ditokenize dihimpun pada array. Hasil dari proses tokenize berupa data array yang dapat digunakan oleh proses cleansing.

f. Cleansing

Tahapan cleansing merupakan tahap pembersihan kata dari atribut yang tidak berpengaruh sama sekali terhadap hasil klasifikasi sentimen. Komponen dokumen tweet memiliki berbagai atribut yang tidak berpengaruh terhadap sentimen, karena setiap tweet memiliki atribut tersebut. Contoh dari atribut yang tidak berpengaruh adalah mention yang diawali dengan atribut ('@), hastag yang diawali dengan atribut ('\#'), link yang diawali dengan atribut ('http','bit.ly') dan karakter simbol $\left(\sim ! @ \# \$ \%^{\wedge} \& *()_{-}+?<>, . ?:\{\}[] \mid\right)$. Atribut yang tidak berpengaruh tersebut akan dihilangkan dari data tweet.

g. Klasifikasi

Setelah melalui tahap preprocessing (tokeninze dan cleansing) data tweet kemudian diklasifikasikan ke dalam sentimen positif, netral dan negatif. Untuk dapat mengenali kalimat positif, netral dan negatif maka dibuat sebuah subjectivity atau kumpulan kata yang memuat kata positif, netral dan negatif yang disimpan pada file excel, tujuannya agar dapat dibaca oleh program, karena sudah ada package yang diinstal untuk membaca file dengan format excel atau csv kemudian data tweet dihitung probabilitasnya menggunakan algoritma naïve bayes.

\section{Data Modeling}

Modeling adalah tahapan untuk membuat model prediktif, yaitu untuk memprediksi sentimen pada data tweet. Pada tahap ini dapat menggunakan statistika dan machine learning untuk mendapatkan insight yang berguna dari data untuk mencapai tujuan penelitian. 
Setelah data tweet melalui proses membaca file subjectivity, kemudian pada tahap ini dihitung probabilitas untuk masing-masing kata sehingga didapat sentimen dari hasil penghitungan probabilitas tersebut, sebagai data uji diambil record dari masing-masing sentimen positif, sentimen negatif dan netral. Jumlah data uji adalah 9 data terdiri dari sentimen positif 3 data, sentimen negatif 3 data dan sentimen netral 3 data. Data latih diperoleh dari penggabungan file data sentimen positif, sentimen negatif dan sentimen netral. Dalam percobaan ini digunakan algoritma Naive Bayes yang dikembangkan untuk CRAN project atau lebih tepatnya library (sentiment) dengan bahasa $\mathrm{R}$ yang dibuat oleh Timothy Jurka. Data latih dan data uji secara bersamaan akan diubah menjadi data vector. Kemudian pada data vector dilakukan proses cleansing. Data vector yang sudah melalui proses cleansing akan diklasifikasikan menggunakan class_polarity sentimen. Dari hasil data cleansing kemudian dihitung probabilitas untuk masing-masing kata, setiap kata pada data tweet hanya dihitung satu kali, jika terdapat kata yang sama dalam satu tweet atau tweet lain maka tidak akan dihitung. Hasil perhitungan probabilitas kemudian digunakan sebagai model probabilistik yang selanjutnya digunakan sebagai data acuan untuk menentukan data testing.

\section{HASIL DAN PEMBAHASAN}

Berikut tampilan proses running source code crawling data berdasarkan keyword pada aplikasi Rstudio

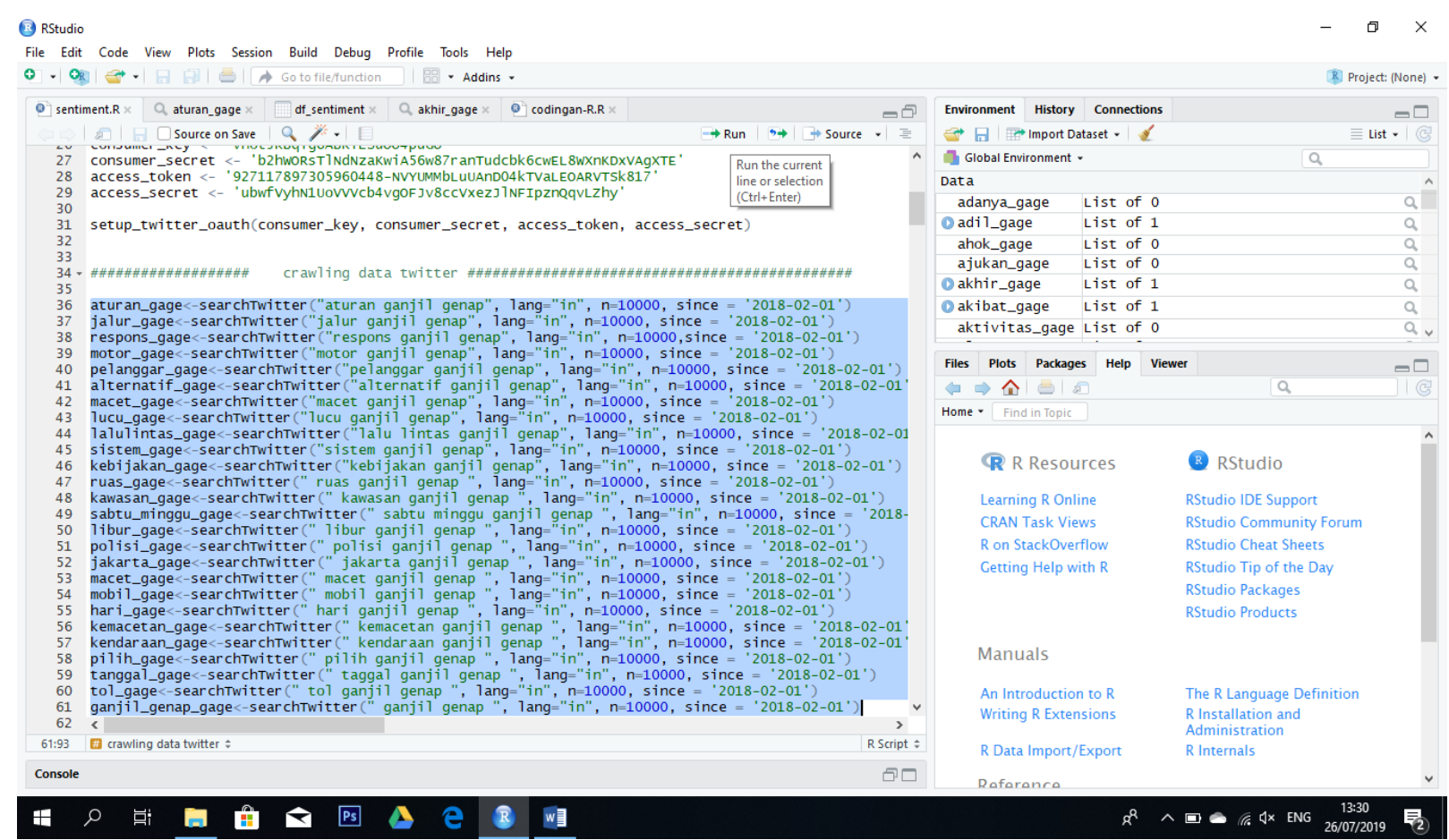

Gambar 1. Proses running source code crawling data 
Setelah dilakukan proses crawling data berdasarkan keyword maka akan didapatkan hasil sebagai berikut : fikan ya aturan ganjil genap diadain lagi. 2 - Taman di jakarta juga udah mulai banyak. @phrinses @pakaititik @HiLucie16 @tubirfess Balik lagi ke gengsi sih. Iya kalau semua orang punya pemikiran naik um... https://t. co/YEPUDZjpe5

4 penambahan lokasi car free day, perluasan aturan ganji1-genap kendaraan, penambahan dan pembaharua n ruang terbuka h... https://t.co/i5shrgLSBk

5 OVERLOAD $\backslash n^{*}$ Cerita Hari Ini \n\nEfek dari aturan ganjil-genap di Jakarta, membuat saya harus meninggal kan mobil di stas... https://t.co/wCXW7gKAs7

6 Melalui sebaran unggahan di media sosial, muncul informasi mengenai pemberlakuan aturan pembatasan operasional kend... https://t.co/KSPIZiPVhm

://t.co/wLlciucxvx https://t.co/RDDkoAh4HB

Viral Aturan Ganji1-Genap 15 Jam Mulai 12 Juli, Ini Faktanya https

8 Melalui sebaran unggahan di media sosia operasional kend... https://t.co/uenRpgBoJj

1, muncul informasi mengenai penber lakuan aturan pembatasan 9 Di jakarta ada aturan ganjil genap. Ada ngk ya warga jakarta saking tajirnya beli 2 mobil yg sa ma tapi 1 mobil plat genap satunya ganjil?

10 Beredar kabar di media sosial soal pemberlakuan nopol ganjil genap di DKI Jakarta untuk $\mathrm{k}$ endaraan roda dua... https://t. co/4r6QpjoFle

11 Beredar Kabar Aturan Ganjil-Genap Sepeda Motor di DKI Jakarta Mulai 18-31 Juli, Cek Faktany a https://t.co/HY20Y6Ilq2 lewat @Tribunwow

12

opol Ganji1 Genap? https://t.co/8dRbegEZ8n

13 acNNIndonesia Ganjil Genap berlaku buat ekonomi menengah kebawah yg kaya punya mobil lebih dari 1 bahkan selain pun... https://t. co/EBLirLwzah

14

uran ganji1 genap apkh ada yg terbaru? Tks

@RadioElshinta mohon info utk at

15 RT asonoraFM92: Sahabat Sonora, saat ini ada beredar kabar di wA grup ttg aturan ganji1 genap sel ama 15 jam yg diberlakukan mulai hari ini

16 Solusi Macet---\nDi Swedia : penerapan ERP \nDenmark : Integrasi Mode1 Transportasi umum $\backslash$ nJakarta : At uran Ganjil Genap... https://t. co/P8AQBghcwi

17 atempometro Aturan ganjil genap itu hanyalah MEMINDAHKAN KEMACETAN \norg tetap bawa mobil tapi lewat jalan tikus. \nYg... https://t.co/D9v5zM8tqu

18 jam mulai dri hari kemarin 12 juli 2019 ?

19 RT @SonoraFM92: Sahabat Sonora, saat ini ada beredar kabar di wA grup ttg aturan ganjil genap sel ama 15 jam yg diberlakukan mulai hari ini...

Gambar 2. Hasil crawling data berdasarkan keyword

Berikut tampilan proses running source code untuk menyimpan data kedalam data frame.

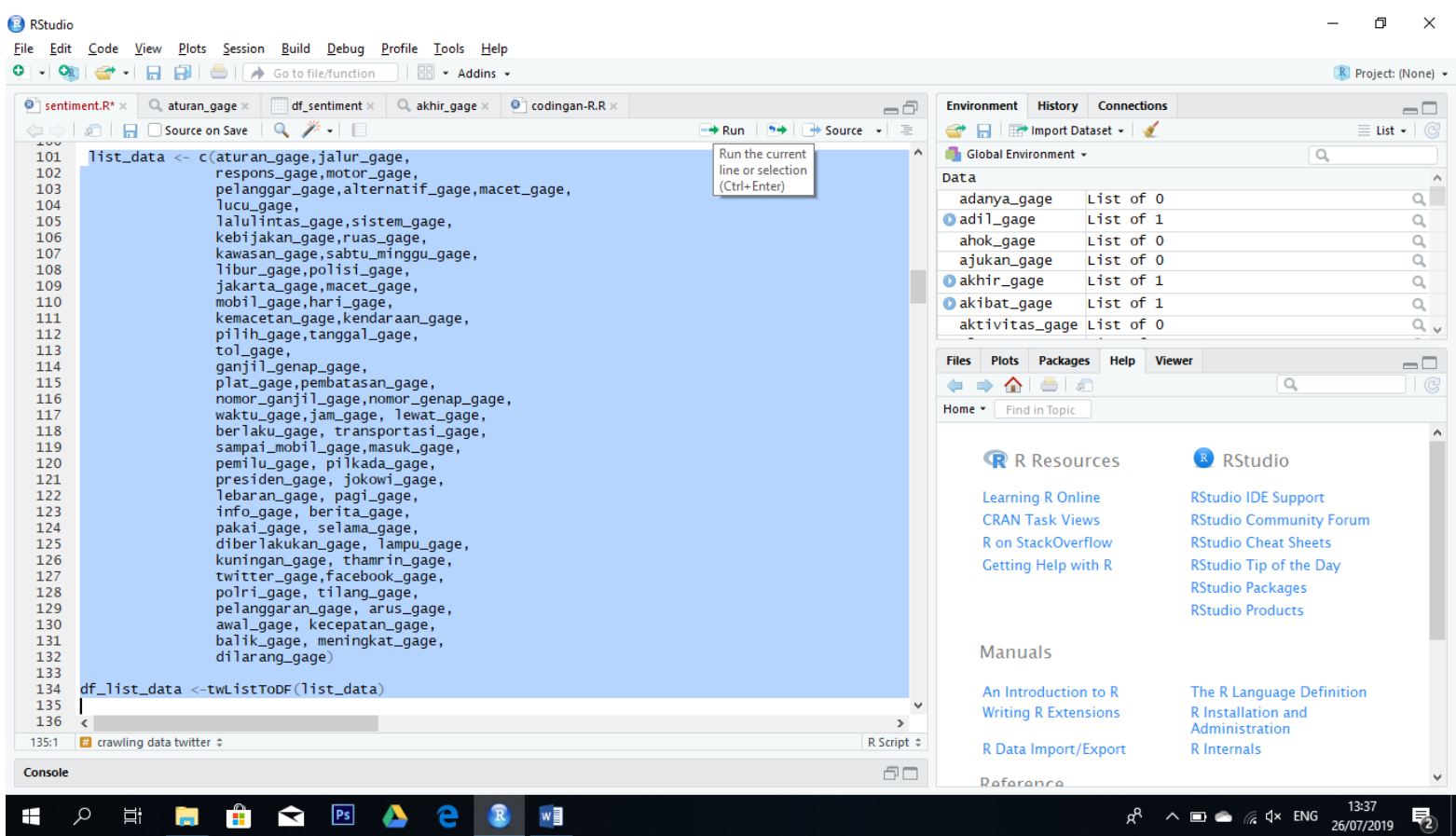

Gambar 3. Proses running source code data frame

http://journal.thamrin.ac.id/index.php/jtik/issue/view/40 
Setelah dilakukan proses running untuk menyimpan data tweet kedalam data frame kemudian hasilnya dapat dilihat sebagai berikut :

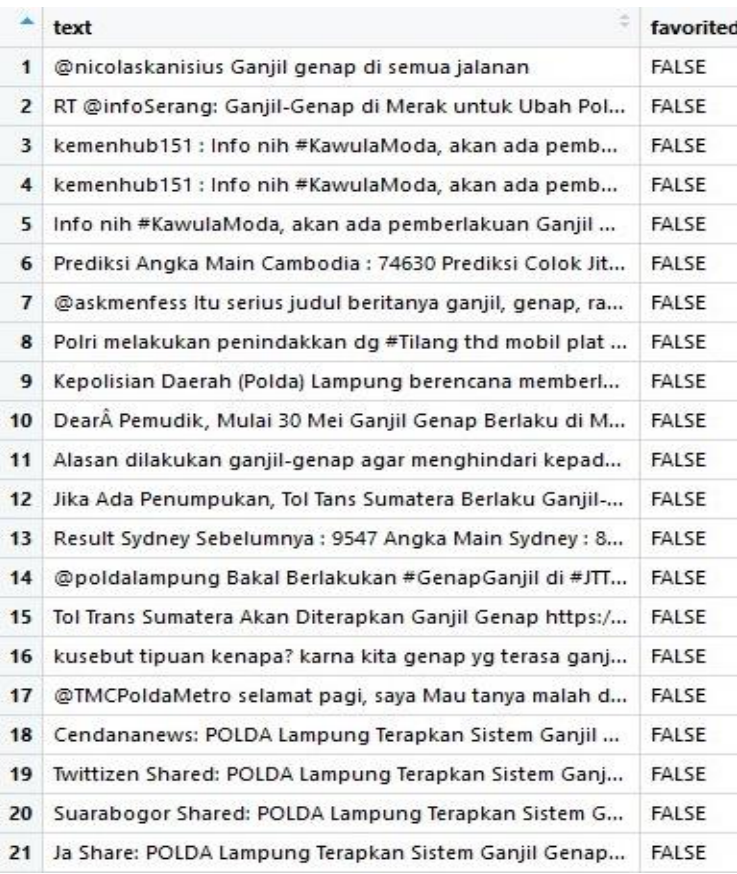

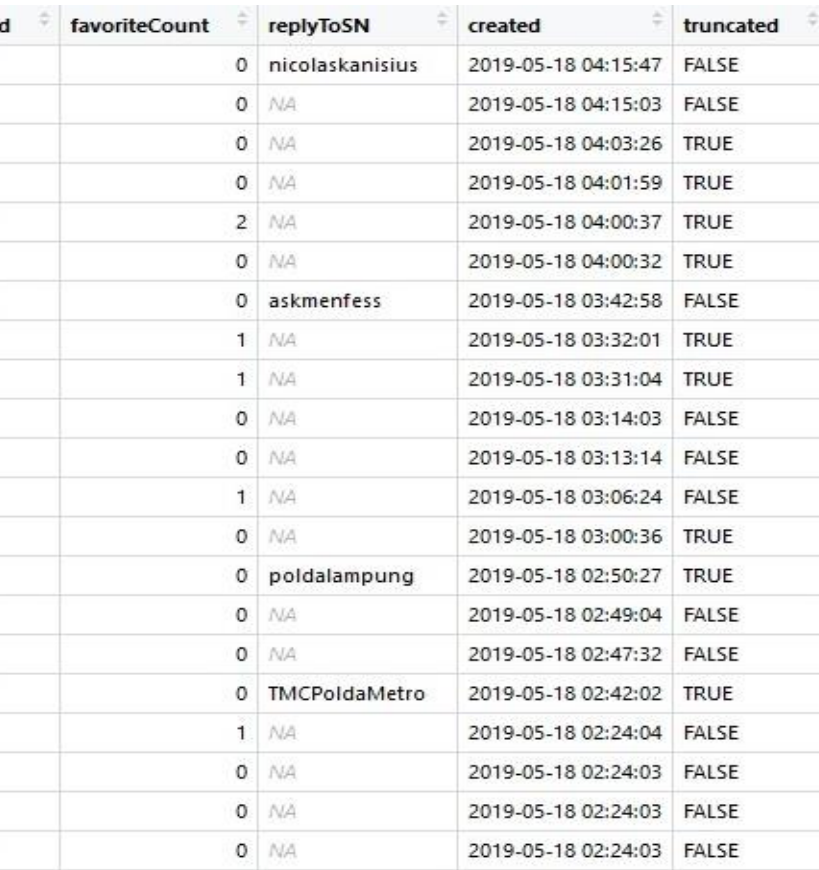

Gambar 4. Data frame

Setelah data tersimpan pada field-field yang ada dalam data frame, berikut field pada data frame yang terdiri dari 16 field dengan struktur dan keterangan sebagai berikut :

Tabel 1. Tabel data frame

\begin{tabular}{|c|l|l|l|}
\hline No. & \multicolumn{1}{|c|}{ Nama field } & \multicolumn{1}{|c|}{ Tipe Data } & \multicolumn{1}{c|}{ Keterangan } \\
\hline 1. & Text & Text & $\begin{array}{l}\text { Tweets/kalimat status yang diposting oleh } \\
\text { pengguna }\end{array}$ \\
\hline 2. & Favourite & Bolean(True/False) & Status favourite True/False \\
\hline 3. & FavouriteCount & Number & $\begin{array}{l}\text { Total berapa kali status ini dijadikan favourite } \\
\text { oleh akun twitter lain }\end{array}$ \\
\hline 4. & replyToSN & String & $\begin{array}{l}\text { Nama pengguna (user screen name) yang me- } \\
\text { retweet status tersebut }\end{array}$ \\
\hline 5. & Created & Timestamp & Tanggal dan jam saat status dibuat/diposting \\
\hline 6. & Truncated & Boolean(True/False) & Status yang diposting (Terpotong/tidak) \\
\hline 7. & replytoSID & String & ID user \\
\hline 8. & Id & String & $\begin{array}{l}\text { ID user penggunga yang membalas status } \\
\text { posting }\end{array}$ \\
\hline 9. & replytoUID & String & Laman sumber \\
\hline 10. & StatusSource & String & Nama layar pengguna yang memposting status \\
\hline 11. & ScreenName & String & $\begin{array}{l}\text { Total jumlah berpa kali status di retweet/dibalas } \\
\text { oleh akun lain }\end{array}$ \\
\hline 12. & retweetCount & Number & \\
\hline 13. & Isretweet & Boolean(True/False) & \\
\hline 14. & Retweeted & Boolean(True/False) & Longitude \\
\hline 15. & Longitude & Geographical & Latitude \\
\hline 16. & Latitude & Geographical & \\
\hline
\end{tabular}


Tampilan proses running source code Tokenize pada aplikasi Rstudio

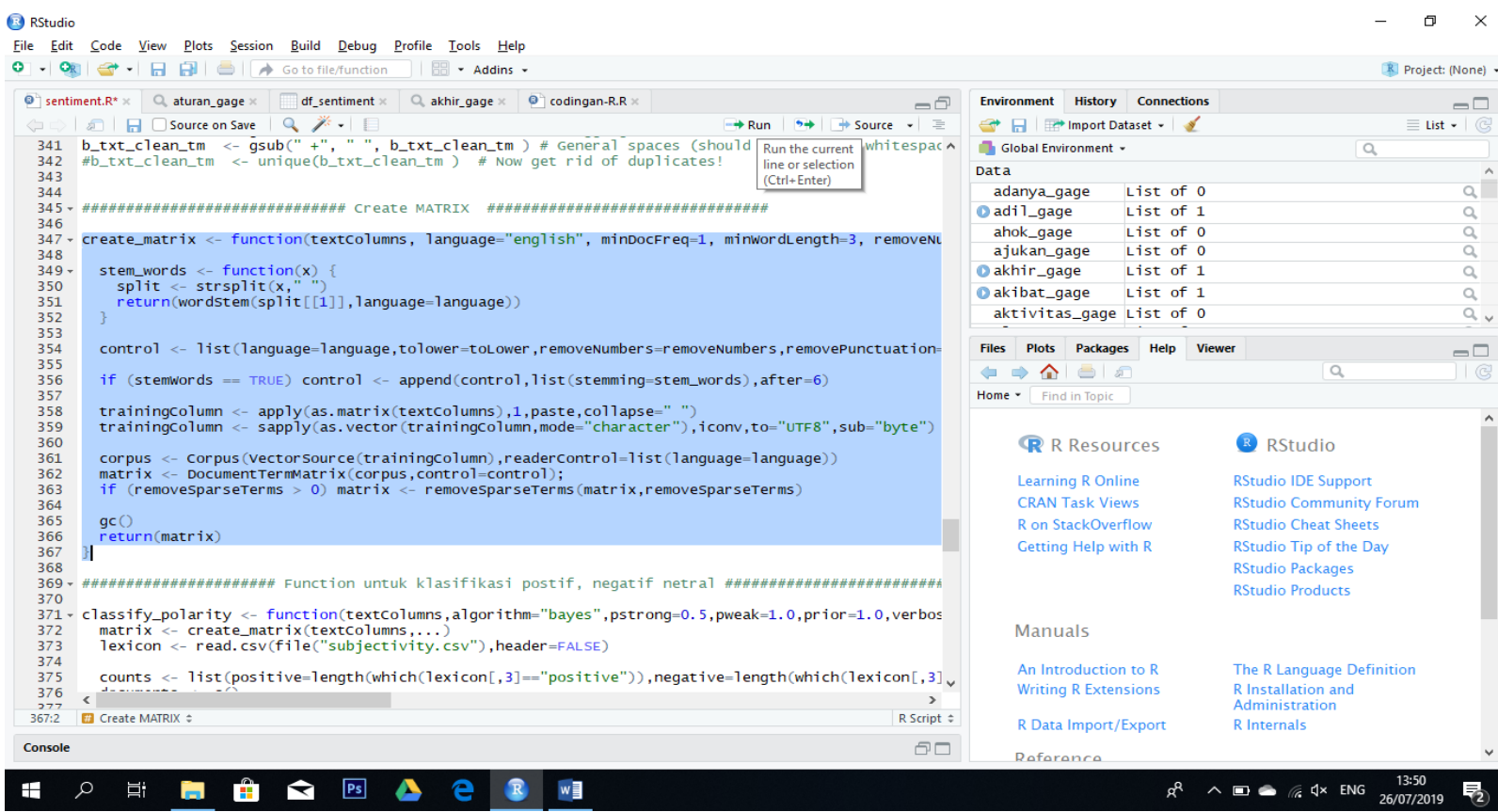

\section{Gambar 5. Proses running source code tokenize}

Proses running souce code cleansing data tweet pada aplikasi Rstudio

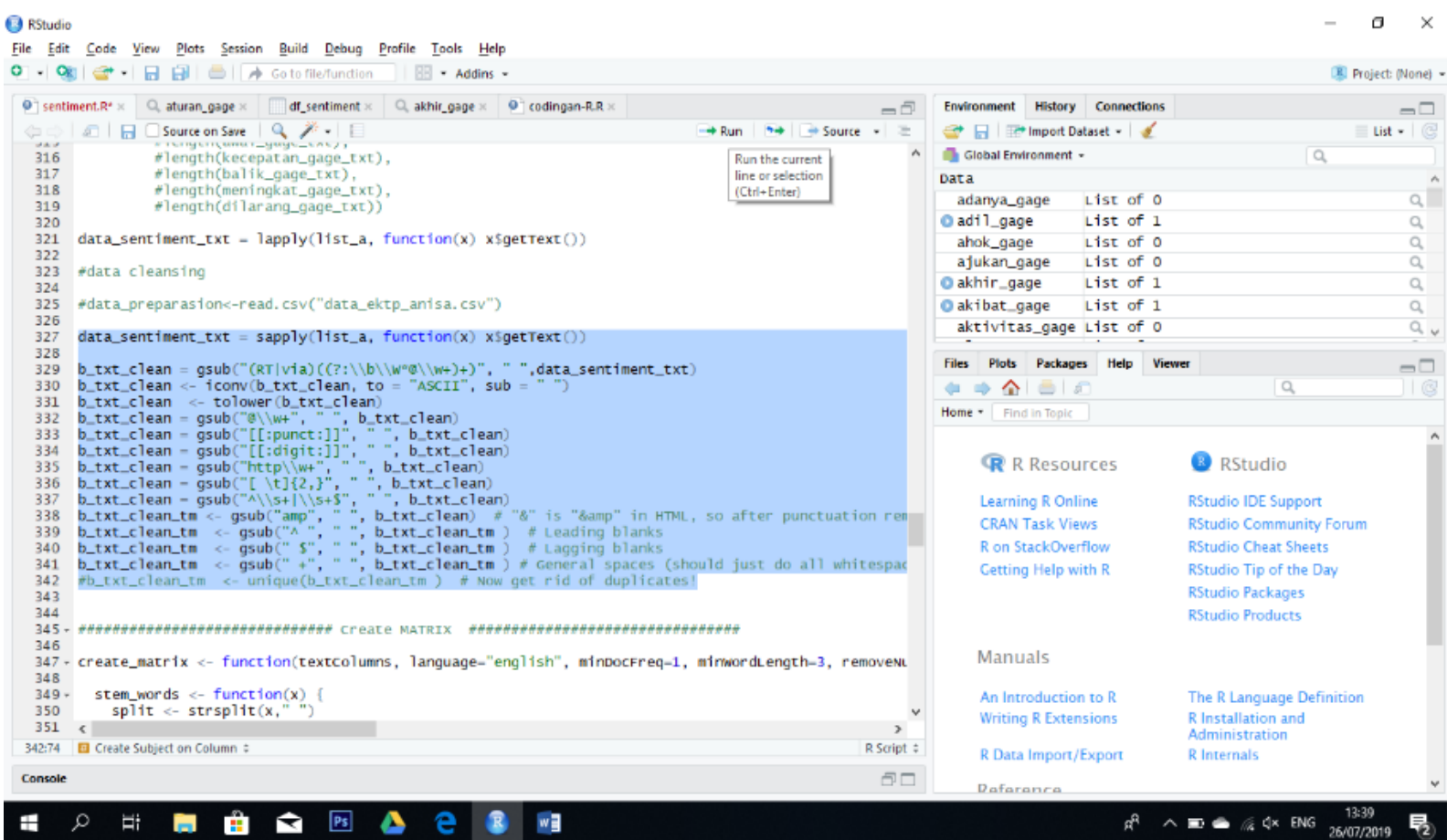

Gambar 6. Proses running source code cleansing

Setelah dilakukan proses cleansing, kemudian hasil cleansing disimpan pada data frame.

Berikut hasil cleansing data yang sudah disimpan pada data frame: 
Volume 7 No 1; Maret 2021

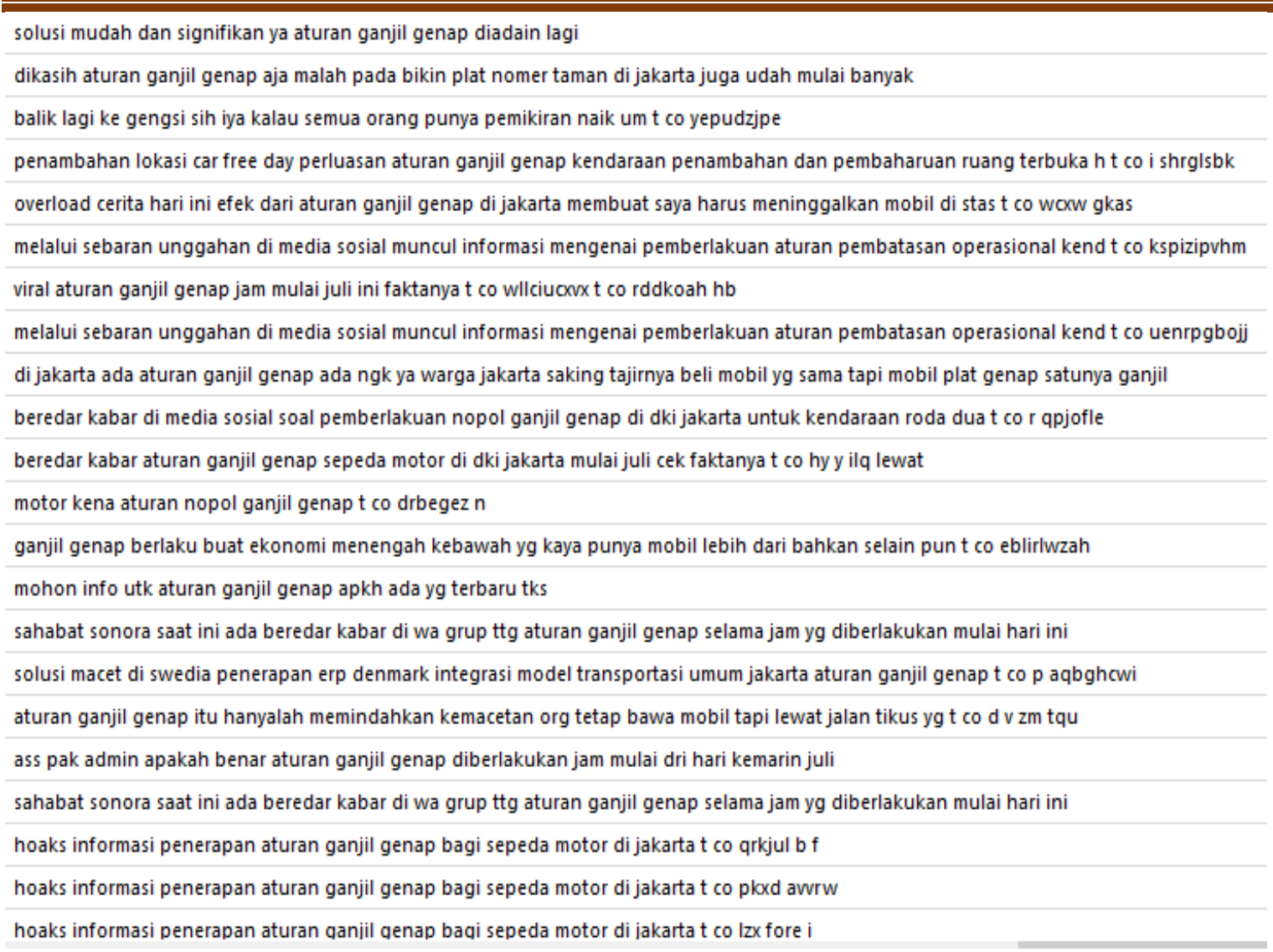

\section{Gambar 7. Hasil cleansing data tweet}

Tampilan proses running source code klasifikasi sentimen positif, netral dan negatif.

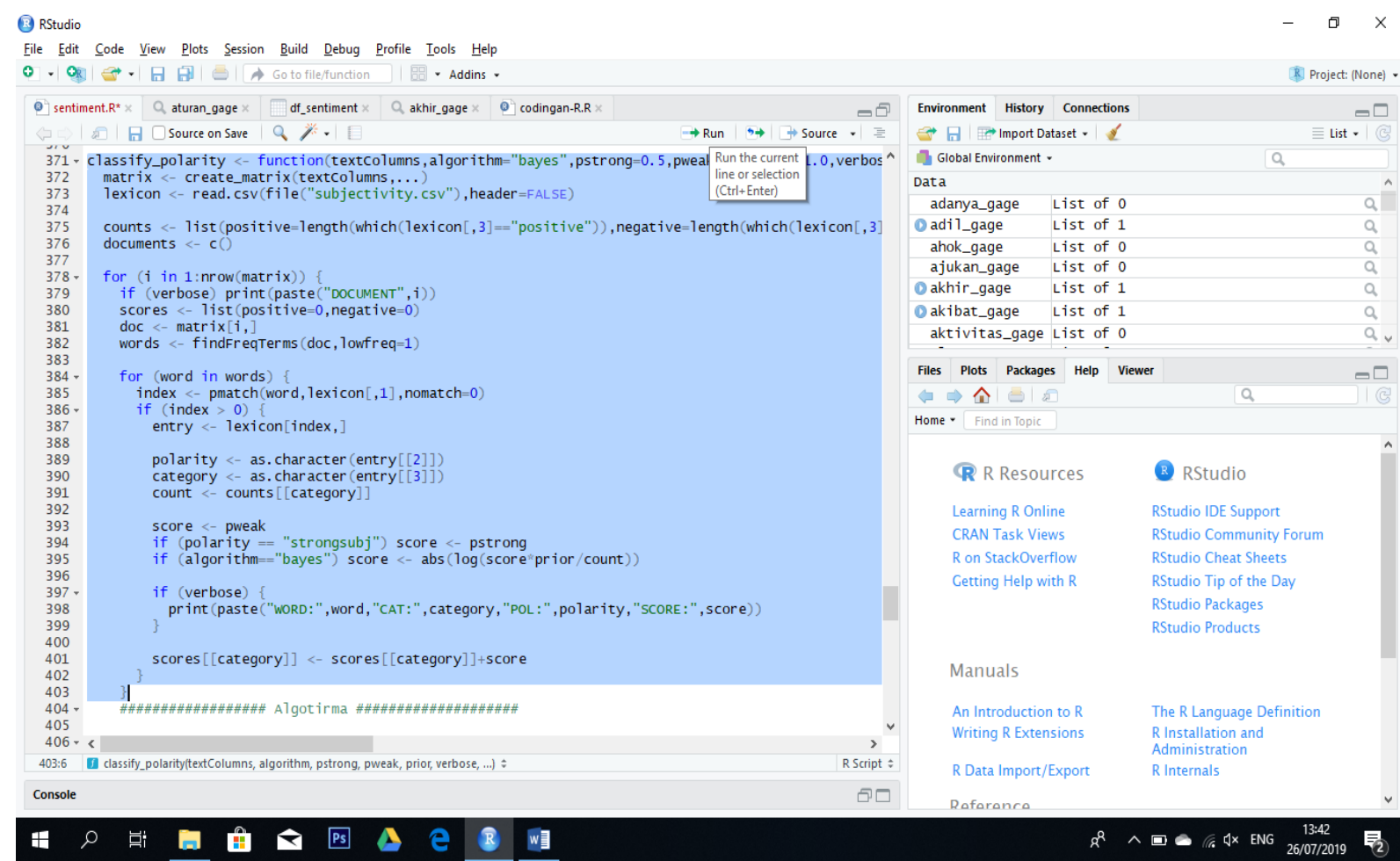

\section{Gambar 8. Proses running souce code klasifikasi}


Berikut hasil modeling dengan menggunakan algoritama naive bayes yang sudah terklasifikasi ke dalam sentimen positif, negatif dan netral :

\begin{tabular}{|c|c|}
\hline positive & solusi mudah dan signifikan ya aturan ganjil genap diadain lagi \\
\hline neutral & dikasih aturan ganjil genap aja malah pada bikin plat nomer taman di jakarta juga udah mulai banyak \\
\hline neutral & balik lagi ke gengsi sih iya kalau semua orang punya pemikiran naik um t co yepudzjpe \\
\hline neutral & penambahan lokasi car free day perluasan aturan ganjil genap kendaraan penambahan dan pembaharuan ruang terbuka $\mathrm{h} t \mathrm{t} c 0$ i shrglsbk \\
\hline positive & overload cerita hari ini efek dari aturan ganjil genap di jakarta membuat saya harus meninggalkan mobil di stas t co woxw gkas \\
\hline neutral & melalui sebaran unggahan di media sosial muncul informasi mengenai pemberlakuan aturan pembatasan operasional kend $\mathrm{t}$ co kspizipvhm \\
\hline neutral & viral aturan ganjil genap jam mulai juli ini faktanya t co wllciucxvx t co rddkoah hb \\
\hline neutral & melalui sebaran unggahan di media sosial muncul informasi mengenai pemberlakuan aturan pembatasan operasional kend t co uenrpgbojj \\
\hline neutral & di jakarta ada aturan ganjil genap ada ngk ya warga jakarta saking tajirnya beli mobil yg sama tapi mobil plat genap satunya ganjil \\
\hline neutral & beredar kabar di media sosial soal pemberlakuan nopol ganjil genap di dki jakarta untuk kendaraan roda dua t co r qpjofle \\
\hline neutral & beredar kabar aturan ganjil genap sepeda motor di dki jakarta mulai juli cek faktanya t co hy y ilq lewat \\
\hline neutral & motor kena aturan nopol ganjil genap t co drbegez $n$ \\
\hline neutral & ganjil genap berlaku buat ekonomi menengah kebawah yg kaya punya mobil lebih dari bahkan selain pun $t$ co eblirlwzah \\
\hline neutral & mohon info utk aturan ganjil genap apkh ada yg terbaru tks \\
\hline neutral & sahabat sonora saat ini ada beredar kabar di wa grup ttg aturan ganjil genap selama jam yg diberlakukan mulai hari ini \\
\hline neutral & solusi macet di swedia penerapan erp denmark integrasi model transportasi umum jakarta aturan ganjil genap t co p aqbghcwi \\
\hline neutral & aturan ganjil genap itu hanyalah memindahkan kemacetan org tetap bawa mobil tapi lewat jalan tikus yg t co d v zm tqu \\
\hline neutral & ass pak admin apakah benar aturan ganjil genap diberlakukan jam mulai dri hari kemarin juli \\
\hline neutral & sahabat sonora saat ini ada beredar kabar di wa grup ttg aturan ganjil genap selama jam yg diberlakukan mulai hari ini \\
\hline neutral & hoaks informasi penerapan aturan ganjil genap bagi sepeda motor di jakarta t co qrkjul b $f$ \\
\hline neutral & hoaks informasi penerapan aturan ganjil genap bagi sepeda motor di jakarta t co pkxd awrw \\
\hline
\end{tabular}

Gambar 9. Hasil klasifikasi dengan penghitungan probabilitas algoritma naive bayes

Hasil modeling yang telah diklasifikasikan kemudian disimpan ke dalam database, namun sebelum disimpan dalam data base perlu dilakukan koneksi ke data base dengan melakukan instal package library (RMySQL) dan library (dbconnect), data base yang digunakan adalah mysql dengan nama data base dbtest. Berikut data hasil modeling yang sudah tersimpan pada data base :

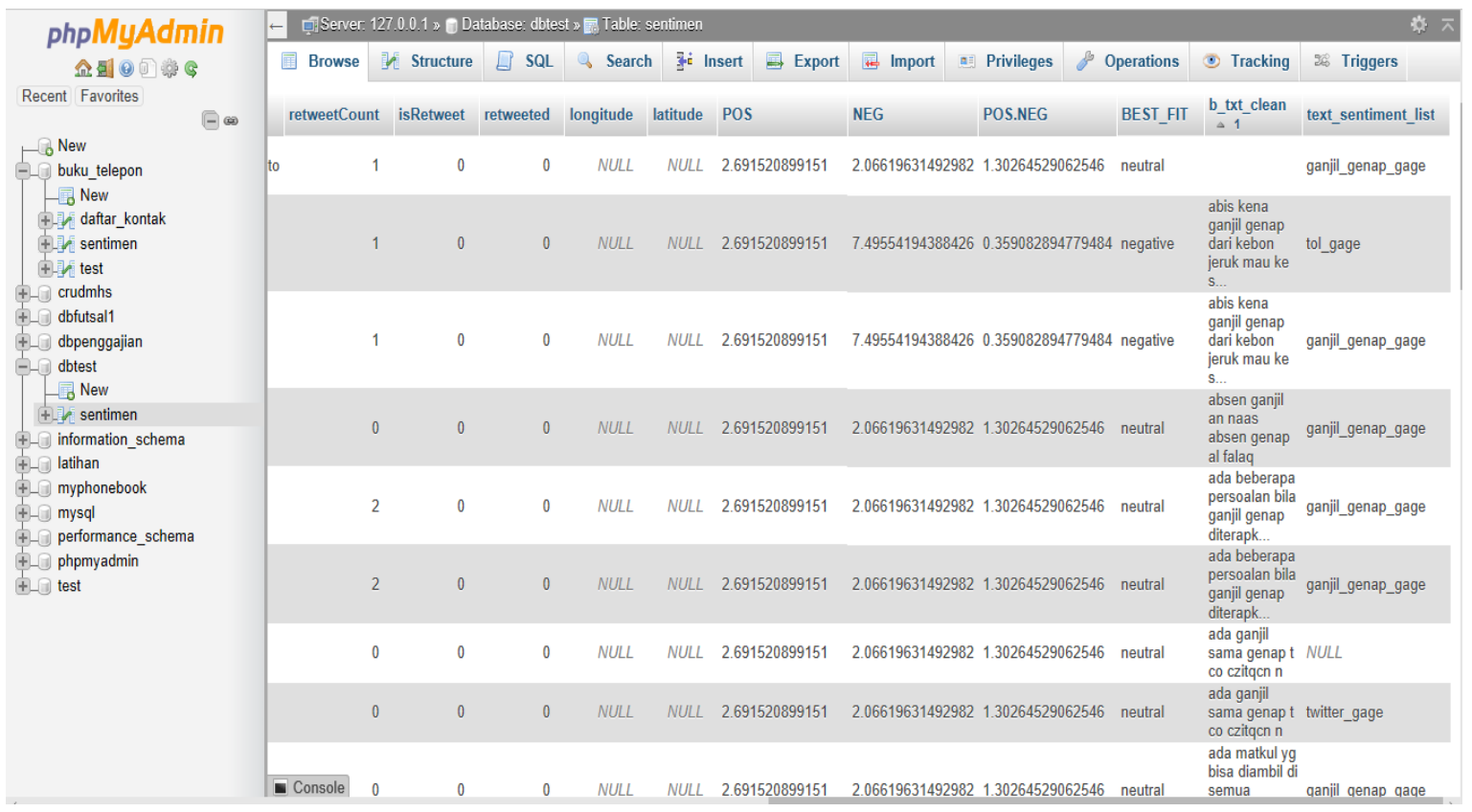

Gambar 10. Data yang telah tersimpan pada database 
Agar data tweet yang telah diklasifikasi mudah untuk dipahami oleh publik maka dilakukan visualisasi data ke dalam sebuah diagram atau tampilan yang mudah dipahami publik, dengan memanfaatkan tableau aplication data tweet divisualisasikan berdasarkan kebutuhan informasi yang akan ditampilkan.

Berikut dashboard sentimen analis perluasan dan perpanjangan ganjil genap di Jakarta, dashboard berupa gabungan dari beberapa visulisasi yang sudah dibuat.

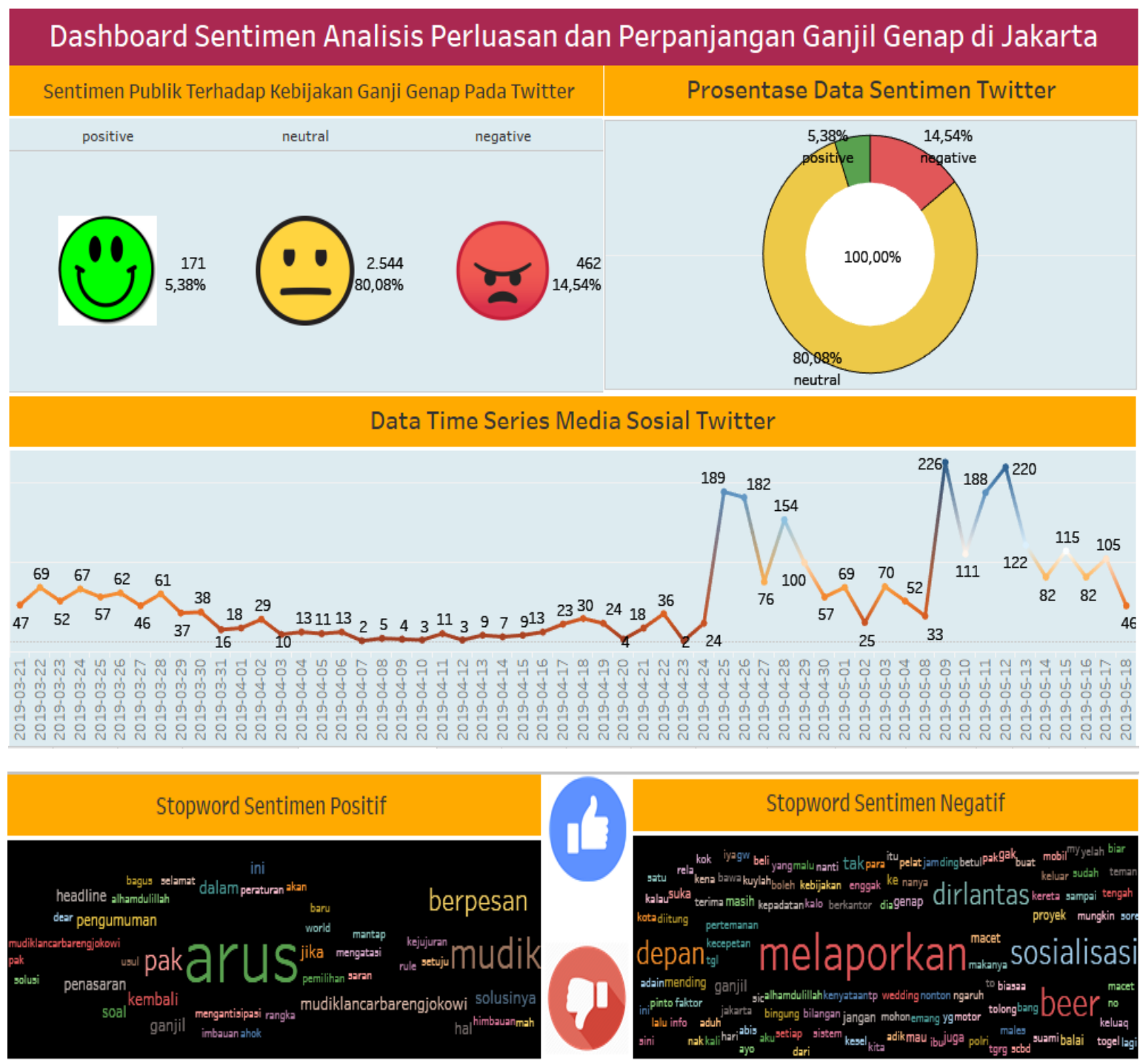

Gambar 11. Visualisasi dashboard

Gambar dashboard perancangan sistem informasi strategis untuk menentukan perpanjangan dan perluasan ganjil genap di wilayah DKI Jakarta, disimpan pada tableau public agar dapat diakses oleh masyarakat luas melalui website. Masyarakat dapat melihat dashboard yang berisi informasi visual mengenai hasil penelitian dengan mengakses website https://public.tableau.com/profile/robbi.rekto.waryono\#!/vizhome/ganjilgenap/ Dashboard1?publish=yes. 
Untuk menilai hasil pemodelan dilakukan dengan pendekatan secara lexicon based, yaitu klasifikasi data tweet berdasarkan lexicon. Lexicon adalah sekumpulan kata/kamus yang berisi kata yang telah dikategorikan sebagai kata positif, netral dan negatif. Semakin banyak perbendaharaan kata pada lexicon maka semakin bagus klasfikasi yang dihasilkan.

Dari total 3117 data yang diperoleh dari proses crawling kemudian diklasifikasikan ke dalam sentimen positif, netral dan negatif didapat hasil bahwa terdapat sentimen positif sebanyak 171 atau 5,38 \% dari total keseluruhan data. Untuk sentimen netral sebanyak 2.544 atau 80,08 \% dari total keseluruhan data. Sedangkan sentimen negatif sebanyak 462 atau $14,54 \%$ dari total keseluruhan data.

\section{KESIMPULAN DAN REKOMENDASI}

Dari uraian mengenai analisis sentimen perpanjangan dan perluasan ganjil genap di wilayah DKI Jakarta dapat disimpulkan bahwa kebijakam ganjil genap merupakan langkah pemerintah DKI Jakarta untuk mengurangi masalah kemacetan di Jakarta, mekanismenya adalah kendaran beroda 4 atau lebih dengan nomor kendaraan digit terakhir ganjil hanya diperbolehkan melintas pada tanggal ganjil dan nomor kendaraan dengan digit terakhir ganap hanya diperbolehkan melintas pada tanggal genap. Setelah dinilai sukses mengurangi kemacetan pemerintah daerah merencanakan untuk memperpanjang dan memperluas ruas jalan yang diberlakukan ganjil genap, namun sebelum menentukan untuk memperpanjang dan memperluas ganjil genap, pemerintah daerah membutuhkan informasi yang dapat digunakan sebagai referensi dalam proses pengambilan keputusan. Sebagai salah satu bahan referensi dalam proses pengambilan keputusan terhadap kebijakan perpanjangan dan perluasan ganjil genap, maka dilakukan dengan mengetahui sentimen masyarakat Jakarta pada media sosial twitter. Dari analisis sentimen yang dilakukan didapatkan sebanyak $80.08 \%$ tweet yang ada menyatakan pandangan yang netral, artinya sebagian besar masyarakat Jakarta tidak menolak dan juga tidak mendukung kebijakan perpanjangan dan perluasan kebijakan ganjil genap tersebut.

\section{REFERENSI}

BPS DKI Jakarta. (2019). Jumlah Kendaraan Bermotor Menurut Jenis Kendaraan (unit) di Provinsi DKI Jakarta 2017-2019. Retrieved February 28, 2021, from Data Sensus website: https://jakarta.bps.go.id/indicator/17/786/1/jumlah-kendaraan-bermotormenurut-jenis-kendaraan-unit-di-provinsi-dki-jakarta.html

Han, J., Kamber, M., \& Pei, J. (2012). Data Mining: Concepts and Techniques (Third Edit). https://doi.org/https://doi.org/10.1016/B978-0-12-381479-1.00001-0 
Kumar, S., Morstatter, F., \& Liu, H. (2014). Twitter Data Analytics. https://doi.org/10.1007/978-1-4614-9372-3

Ruhyana, N. (2019). Analisis Sentimen Terhadap Penerapan Sistem Plat Nomor Ganjil/Genap Pada Twitter Dengan Metode Klasifikasi Naive Bayes. Jurnal IKRAITH Informatika, 3(1), 94-99. Retrieved from https://journals.upiyai.ac.id/index.php/ikraith-informatika/article/view/304/196

Shneiderman, B., Plaisant, C., Cohen, M., Jacobs, S., Elmqvist, N., \& Diakopoulos, N. (2016). Designing the User Interface: Strategies for Effective Human-Computer Interaction (6th Editio). Essex UK: Pearson.

Suhanda, Y., Kurniati, I., \& Norma, S. (2020). Penerapan Metode Crisp-DM dengan Algoritma K-Means Clustering Untuk Segmentasi Mahasiswa Berdasarkan Kualitas Akademik. Jurnal Teknologi Informatika Dan Komputer MH Thamrin, 6(2), 12-20. https://doi.org/https://doi.org/10.37012/jtik.v6i2.299

Yanti, D. S. A., Indriati, \& Adikara, P. P. (2019). Analisis Sentimen Tentang Kebijakan Ganjil Genap Kendaraan Bermotor di DKI Jakarta Pada Twitter Menggunakan BM25 dan K-Nearest Neighbor. Jurnal Pengembangan Teknlogi Informasi Dan Ilmu Komputer, 3(3), 2626-2631. Retrieved from http://j-ptiik.ub.ac.id/index.php/jptiik/article/view/4764 